\title{
Half a century of changing mercury levels in Swedish freshwater fish
}

\author{
Staffan Åkerblom, Anders Bignert, Markus Meili, \\ Lars Sonesten, Marcus Sundbom
}

\begin{abstract}
The variability of mercury $(\mathrm{Hg})$ levels in Swedish freshwater fish during almost 50 years was assessed based on a compilation of 44927 observations from 2881 waters. To obtain comparable values, individual $\mathrm{Hg}$ concentrations of fish from any species and of any size were normalized to correspond to a standard 1-kg pike [median: $0.69 \mathrm{mg} \mathrm{kg}^{-1}$ wet weight (ww), mean $\pm \mathrm{SD}$ : $0.84 \pm 0.67 \mathrm{mg} \mathrm{kg}^{-1} \mathrm{ww}$. The EU Environmental Quality Standard of $0.02 \mathrm{mg} \mathrm{kg}^{-1}$ was exceeded in all waters, while the guideline set by $\mathrm{FAO} / \mathrm{WHO}$ for $\mathrm{Hg}$ levels in fish used for human consumption $\left(0.5-1.0 \mathrm{mg} \mathrm{kg}^{-1}\right)$ was exceeded in $52.5 \%$ of Swedish waters after 2000. Different trend analysis approaches indicated an overall long-term decline of at least $20 \%$ during 1965-2012 but trends did not follow any consistent regional pattern. During the latest decade (2003-2012), however, a spatial gradient has emerged with decreasing trends predominating in southwestern Sweden.
\end{abstract}

Keywords Mercury · Freshwater .

Environmental Quality Standard · Trend analysis

\section{INTRODUCTION}

High mercury $(\mathrm{Hg})$ levels in the environment have been of concern in Sweden since they were recognized during the late 1950s in dead birds contaminated by fungicide-treated seed (Borg 1959; Borg et al. 1965), and during the 1960s also in freshwater fish in remote areas (Johnels et al. 1967; Ackefors 1971). Freshwater fish is a dominant source of $\mathrm{Hg}$ to birds and mammals feeding on fish (Basu et al. 2005; Evers et al. 2008). Human intake of $\mathrm{Hg}$ from predatory fish and other aquatic foods is considered a serious exposure route (NFA 2012). Human hair Hg levels, a good indicator of $\mathrm{Hg}$ exposure to humans, are positively correlated to the consumption frequency of freshwater fish in Swedish angling societies (Johnsson et al. 2004). The presence of organic pollutants might have an ecotoxicological effect on wildlife that makes the effect from $\mathrm{Hg}$ difficult to distinguish. For instance, an increase in Swedish otter populations between 1968 and 1999 coincided with a decrease in otter polychlorinated biphenyl (PCB) concentrations but did not relate to an apparent increase in $\mathrm{Hg}$ concentrations in otters (Roos et al. 2001). The exposure of $\mathrm{Hg}$ from small fish species to piscivorous birds during egg laying and hatching was significant compared to other periods (Eagles-Smith and Ackerman 2009). This imposes that selection of size and species for monitoring purposes, and also timing for field collection, needs to be considered in the strategic design of monitoring programs.

While total $\mathrm{Hg}$ is usually analyzed and reported in environmental monitoring programs, it is its organic form, methyl$\mathrm{Hg}^{+}(\mathrm{MeHg})$, that biomagnifies and exerts serious neurotoxic effects on humans and wildlife (Chan et al. 2003; Mergler et al. 2007; Scheuhammer et al. 2007). The proportion of $\mathrm{MeHg}$ relative total $\mathrm{Hg}$ increases in the food web, from $15 \%$ in phytoplankton to $>95 \%$ in fish (Watras and Bloom 1992). Ecologically relevant toxicity thresholds for dietary exposure of $\mathrm{MeHg}$ in fish have been proposed in the range 0.10 $0.40 \mathrm{mg} \mathrm{kg}^{-1}$ wet weight (ww) (cf. Depew et al. 2012). To prevent potential negative ecological effects in fish-feeding communities, an assessment factor of 10 is applied to derive toxic thresholds, i.e., Environmental Quality Standard (EQS) (EC 2011). The EQS for $\mathrm{Hg}$ in freshwater biota is by this approach set to $0.02 \mathrm{mg} \mathrm{Hg} \mathrm{kg}^{-1}$ ww by the EU Water Framework Directive (WFD) (EP 2008). Based on risk assessments and other societal considerations, the Food and Agriculture Organization/World Health Organization (FAO/ WHO) (CA 1995) and European Commission (EC 2006) use 
advisory levels of $0.5-1.0 \mathrm{mg} \mathrm{MeHg} \mathrm{kg}^{-1} \mathrm{ww}$ in fish that are considered safe for human consumption. Considering these health advisory guidelines and in the light of current levels in the environment, the ability to detect trends and understand processes from existing datasets is crucial in the evaluation of societal actions with the aim of reducing $\mathrm{Hg}$ levels in freshwater biota.

Measures to combat consequences related to high $\mathrm{Hg}$ concentrations in freshwater fish have been deployed in Sweden by various means, e.g., prohibiting consumption of fish from targeted lakes and health advisory guidelines by the Swedish National Food Agency (Ohlin 1982; Björklund et al. 1984; Petersson-Grawé et al. 2007; NFA 2012). As $\mathrm{Hg}$ contamination became recognized as a transboundary and global problem, international agreements have been implemented with the aim to reduce fish $\mathrm{Hg}$ concentrations, i.e., critical load estimations for the convention on longrange transboundary air-pollution (CLRTAP 2003) and classification of water bodies based on the WFD EQS (EP 2000). In November 2013, the Minamata Convention on Mercury was signed by 93 countries with the aim of globally protecting human health and the environment from the adverse effects of $\mathrm{Hg}$ (UNEP 2013). Monitoring programs are needed to evaluate the effects of environmental policies and societal management activities with the aim of supporting national and global treaties, and to establish recommendations to protect human health and ecosystems from the effects from $\mathrm{Hg}$ contamination. In this context, the availability of long-term monitoring data of $\mathrm{Hg}$ from freshwater ecosystems is required to evaluate if measures taken to decrease exposure of $\mathrm{Hg}$ to humans and wildlife are efficient.

The challenge in detection of temporal trends is to separate non-temporal variance within and among lakes (e.g., effects of trophic magnification, growth rate or body size) from spatiotemporal patterns in fish $\mathrm{Hg}$ levels (e.g., Johnels et al. 1967; Lindqvist et al. 1991; Watras et al. 1998; Lavoie et al. 2013). Non-temporal variance often contributes most to variability and operates both within and among lakes (Sonesten 2003a). To overcome the effect of a size-Hg relationship, normalization to a standard 1-kg pike has long been applied for comparison of fish $\mathrm{Hg}$ concentrations across lakes and regions and over time (Olsson 1976; Håkanson et al. 1988; Meili et al. 2004a, b). To transform fish $\mathrm{Hg}$ concentrations to correspond to a standard 1-kg pike, various techniques have been applied, such as dividing the $\mathrm{Hg}$ concentration by the fish weight (Johnels et al. 1967; Björklund et al. 1984; Sonesten 2003a), selection of fish $\mathrm{Hg}$ data within specific size ranges (Sonesten 2003a; Åkerblom et al. 2012), linear regression on weight (Håkanson et al. 1988; Lindqvist et al. 1991), or individual normalization using non-linear species-specific transfer functions (Meili et al. 2004a, b; Munthe et al.
2004). The latter permits the normalization of fish Hg data both across fish species and on an individual basis without assumptions of linearity, for example, to generate a standard 1-kg pike value also for lakes without pike. Temporal trends in fish $\mathrm{Hg}$ concentrations have previously been assessed statistically by means of linear regressions (Håkanson et al. 1988; Johansson et al. 2001; Miller et al. 2013), $t$ tests (Miller et al. 2013), and $z$ tests of proportions of lakes (Åkerblom et al. 2012), but all these methods have limitations in describing non-linear changes and fluctuations. An application of generalized additive models (GAMs) provides the opportunity to capture non-linear trends and allow for the estimation of underlying trends in environmental data (Wood 2011).

The aim of this study was to explore spatial and temporal patterns of $\mathrm{Hg}$ concentrations in freshwater fish in Sweden over the past 50 years. $\mathrm{Hg}$ concentrations in Swedish freshwater biota have been collected regularly since the late 1960s, and are in care by the national data host (www.ivl.se), commissioned by the Swedish Environmental Protection Agency (www.swedishepa.se). The data from Swedish monitoring programs of $\mathrm{Hg}$ in freshwater biota include several fish species (mainly northern pike (Esox lucius), Eurasian perch (Perca fluviatilis), and Arctic charr (Salvelinus alpinus); Table 1) and lake types with varying capacity for trophic transfer of $\mathrm{Hg}$. This study will address spatial patterns and temporal trends in fish $\mathrm{Hg}$ concentrations to be discerned after almost 50 years of collecting $\mathrm{Hg}$ data in Swedish freshwater fish, in particular the most recent temporal trends (2003-2012) based on systematic annual monitoring. We have used three approaches here. First, the spatial and temporal pattern for the entire studied period is described using the whole dataset normalized to a standard 1-kg pike. Second, longterm changes as well as their spatial patterns are studied using a subset of resampled waters (lakes and streams/ rivers) that have been sampled during two time periods: 1965-1990 and 1991-2012. Finally, trends during the latest decade are analyzed using a subset of annually sampled lakes from the national monitoring program. Apart from these approaches, we will provide an overview of available and public data derived from Swedish $\mathrm{Hg}$ monitoring and survey efforts over 50 years. The geographic coverage of Swedish data will be compared with that of fish $\mathrm{Hg}$ databases in Canada and the USA.

\section{MATERIALS AND METHODS}

\section{Data acquisition}

The bulk of data used in this study was retrieved from the Swedish national data host, Swedish Environmental 
Table 1 Overview of the content of the database compiled for this study: fish species and their number of samples and lakes with $\mathrm{Hg}$ concentrations and first and last year of reported data

\begin{tabular}{|c|c|c|c|c|c|c|c|}
\hline \multirow[t]{3}{*}{ Fish species } & \multirow[t]{3}{*}{ No. of specimens } & \multirow[t]{3}{*}{ No. of lakes (Catch per lake) } & \multicolumn{4}{|c|}{$\mathrm{Hg}\left(\mathrm{mg} \mathrm{kg}^{-1} \mathrm{ww}\right)$} & \multirow[t]{3}{*}{ First/last year } \\
\hline & & & \multicolumn{2}{|c|}{ Mean $^{\mathrm{a}}$} & \multirow[t]{2}{*}{ Median } & \multirow{2}{*}{$\begin{array}{l}\text { Quantiles } \\
10 / 90\end{array}$} & \\
\hline & & & $\mathrm{AM}$ & GM & & & \\
\hline Northern pike (Esox lucius) & 26823 & $2649(10.1)$ & 0.77 & 0.64 & 0.68 & $0.28 / 1.30$ & $1966 / 2012$ \\
\hline Perch (Perca fluviatilis) & 16287 & $484(33.7)$ & 0.27 & 0.19 & 0.18 & $0.07 / 0.57$ & $1968 / 2012$ \\
\hline Arctic charr (Salvelinus alpinus) & 625 & $17(36.8)$ & 0.13 & 0.08 & 0.09 & $0.03 / 0.34$ & $1965 / 2012$ \\
\hline Roach (Rutilus rutilus) & 823 & $28(29.4)$ & 0.27 & 0.22 & 0.21 & $0.10 / 0.52$ & $1975 / 2011$ \\
\hline Lake trout (Salmo trutta) & 144 & $19(7.6)$ & 0.22 & 0.15 & 0.16 & $0.03 / 0.49$ & $1982 / 2012$ \\
\hline Other (10 species) & 225 & $36(6.3)$ & 0.23 & 0.15 & 0.14 & $0.05 / 0.44$ & 1969/2012 \\
\hline
\end{tabular}

${ }^{a}$ Mean of $\mathrm{Hg}$ concentrations presented as arithmetic mean (AM) and geometric mean (GM)

Research Institute (www.ivl.se), which is contracted to store all records on $\mathrm{Hg}$ and other environmentally hazardous substances in biota collected within national and regional monitoring programs and surveys. Strategies for data collection range from carefully designed monitoring programs bound by long-term commitments aimed for environmental assessment to screening initiatives focusing on human consumption of freshwater fish. The former category belongs to the national monitoring program for $\mathrm{Hg}$ in freshwater fish, which is coordinated by the Swedish Museum of Natural History (SMNH) that supports the annual collection and analysis of perch, pike, and Arctic charr from a total of 32 lakes (SMNH 2011). Another national program, maintained by Integrated Studies of the Effects of Liming Acidified Waters (ISELAW), has followed $\mathrm{Hg}$ concentrations in young perch in a total of 23 limed and acidic lakes (Sundbom 2009). Waters and samples of fish $\mathrm{Hg}$ outside the two nationally coordinated programs were classified as regionally coordinated survey programs. To close identified gaps in the dataset that was downloaded directly from the data host (on December 11, 2013), we collected data from the main $\mathrm{Hg}$ analysis laboratory involved in national and other fish monitoring (ITM, Stockholm University). These included newer data not yet reported to the data host as well as $\mathrm{Hg}$ data from older national, regional, or research programs. Non-fish biota and duplicate records were excluded from the dataset before further analysis.

\section{Transformations and statistics}

To improve comparability of $\mathrm{Hg}$ concentrations among fish of different size and species, and among sites in space and time, observed individual $\mathrm{Hg}$ concentrations $\left([\mathrm{Hg}]_{\mathrm{obs}}\right)$ were standardized to correspond to a $1-\mathrm{kg}$ pike in the same lake $\left([\mathrm{Hg}]_{\mathrm{std}}\right)$, based on an empirically supported transfer function applicable to any fish species at any site, as described in a UN/ECE manual (Meili et al. 2004b):
$[\mathrm{Hg}]_{\mathrm{std}}=[\mathrm{Hg}]_{\mathrm{obs}} /\left(f_{\mathrm{HgY}}+f_{\mathrm{HgW}} W^{2 / 3}\right)$

where $\mathrm{W}$ is the fish body weight in $\mathrm{kg}$ (taken as a unitless value), $\mathrm{f}_{\mathrm{HgY}}$ a parameter representing the concentration ratio between newly hatched young fish and 1-kg pike, and $\mathrm{f}_{\mathrm{HgW}}$ a species-specific empirical coefficient. Parameters were set to default values (Meili et al. 2004b) derived from a large database (Munthe et al. 2004), except for a minor adaptation for large perch (based on Meili et al. 2004a), and a representative bulk value for rare individuals of other species (cf. Meili et al. 2004b): $\mathrm{f}_{\mathrm{HgY}}$ to 0.13 and $\mathrm{f}_{\mathrm{HgW}}$ to 0.87 for pike, 1.65 for perch, and 1 for other species. Additionally, for the evaluation of recent trends in national monitoring lakes, where large amounts of single-species data allow for a stable site-specific normalization, $\log \mathrm{Hg}$ concentrations were normalized by ANCOVA using fish body length and age as covariates prior to trend estimation by linear regression on the residuals from the ANCOVA model.

Several approaches were used to analyze temporal trends and spatial patterns. First, linear regression and GAM were fitted on log-transformed and normalized (1-kg pike) $\mathrm{Hg}$ concentrations $\left([\mathrm{Hg}]_{\text {std }}\right)$. GAM is useful for analyzing non-linear relationships by combining the ease of interpretation of linear models with the flexibility of nonparametric smoothing techniques. Here, a simple GAM with $\mathrm{Hg}$ as response variable and a smoothing function of time as the single explanatory variable was fitted to (1) all data, (2) subset of lime-treated lakes, and (3) a subset of non-limed lakes. A lake was classified as limed if it had been subject to liming at any time during the study period according to the national liming database (http:// kalkdatabasen.lansstyrelsen.se). The GAMs were fitted using R (package mgcv 1.7-28, Wood 2011) with default settings (link function: identity; family: gaussian) and cross validation to determine the optimal degree of smoothing. A second approach using a paired $t$ test was applied to compare $\mathrm{Hg}$ concentrations in fish from resampled waters 
between two time periods (1965-1990 and 1991-2012). Finally, on the same subset of matched lakes, spatial trend surface tests were employed with the spatiostatistical software TISS (Thematic Images and Spatial Statistics), and all descriptive statistics regression and ANCOVA analysis were assisted by JMP 11.0 (SAS Institute Inc., Cary, NC, USA). The significance level was set to $5 \%$ for all tests.

\section{RESULTS AND DISCUSSION}

\section{Swedish fish Hg database}

The extended database contained 44927 observations on fish $\mathrm{Hg}$ concentrations from 15 species in 2881 waters in Sweden (Table 1). The dataset was based mainly $(>99.2 \%)$ on $\mathrm{Hg}$ in fish muscle tissue from pike (59.7\%), perch (36.2\%), roach (Rutilus rutilus, $1.8 \%$ ), and Arctic charr $(1.4 \%)$. For the major fish species, the highest median $\mathrm{Hg}$ concentrations were found in pike, followed by roach, perch, and Arctic charr (Table 1). Hg concentrations in roach are usually lower than in perch (e.g., Meili 1991; Sharma et al. 2008). Within few lakes $(n=11)$ in which roach have been sampled along with perch, the $\mathrm{Hg}$ concentrations in perch were higher compared to roach (data not shown). The order in which Hg concentrations differed between fish (Table 1) was thus partly an effect of skewness in sampled waters, species and fish size there in.

Transfer functions normalizing $\mathrm{Hg}$ concentrations to represent $\mathrm{Hg}$ in a typical 1-kg pike was applied to overcome skewnesses in differences in collected species between waters, regions and time periods, and fish size. The application of transfer function was possible for 42000 data points in the dataset with a mean $\pm \mathrm{SD}[\mathrm{Hg}]_{\text {std }}$ of $0.84 \pm 0.67 \mathrm{mg} \mathrm{kg}^{-1}$ ww (median $=0.69 \mathrm{mg} \mathrm{kg}^{-1}$ ww) (Fig. 1). In order to test the performance of the transfer function, we identified 200 instances where $\mathrm{Hg}$ had been determined in both perch and pike from the same lake within a month's time. Observed $\mathrm{Hg}$ concentrations were on average $24 \%$ higher in pike than in perch (paired $t$ test on $\log \mathrm{Hg}, p<0.001, n=200$ ). After normalization to 1 $\mathrm{kg}$ pike, this difference between sympatric pike (median length $=46 \mathrm{~cm}$ ) and perch (median length $=21 \mathrm{~cm}$ ) narrowed down to only $0.9 \%$ and was not statistically significant (paired $t$ test on log Hg 1-kg pike, $p=0.76$ ). The transfer function was also successful in dampening the $\mathrm{Hg}$ size relationship within species. The regression slope for $\log \mathrm{Hg}$ vs fish length was calculated for 894 subsets of perch and 334 subsets of pike, each with $>10$ individuals caught within the same month and lake. The median slope (\% per $\mathrm{cm}$ ) decreased from 7.8 to 0.2 in perch and from 2.9 to -0.3 in pike after the transfer function was applied. Thus, the transfer function proved to adequately account for typical relationships between $\mathrm{Hg}$ concentrations and both body size and fish species, based on a minimum of preset parameters.

Of the two major fish species in the database, the median sample size of the number of fish from the same year and lake individually analyzed for $\mathrm{Hg}$ was 5 for pike (minmax: 1-170) and 10 for perch (1-76). 1427 waters were sampled only once within a single year, while 1228 waters were sampled more than 1 year. The median length of the time series from the repeatedly sampled waters was 9 years. A total of 246 waters had time series extending between 20 and 45 years. The lake with the longest annual time series, Lake Stensjön in Tyresta National Park, has been analyzed for 36 consecutive years between 1977 and 2012.

The relative number of reported specimens and waters per area was estimated for the Swedish database based on the total area of Swedish land and water and the area of water (Table 2). The relative density of specimen per unit water and land area in Sweden was considerably higher compared to fish $\mathrm{Hg}$ databases from Canada, covering 40 years with reported data from various monitoring and research programs (Depew et al. 2013) and databases on fish $\mathrm{Hg}$ concentrations collected by federal, state, and local agencies in the USA (Chalmers et al. 2011). Databases on $\mathrm{Hg}$ in fish from the Great Lakes region (Monson et al. 2011) and Ontario (Gandhi et al. 2014) also withhold compilations on $\mathrm{Hg}$ in fish from a large, densely populated region, and were included for comparison of fish $\mathrm{Hg}$ monitoring efforts. The North American studies were based on regional and national databases and considered comparable to the database in this study. This type of comparison gives an indication of the efforts between countries to perform fish $\mathrm{Hg}$ monitoring. It is important; however, to note that it does not justify the database quality since the possibility for evaluation of spatial or temporal trends depends on the representativeness of sampled waters and fish species within individual studies.

\section{Strategies of Swedish freshwater monitoring of $\mathbf{H g}$ in biota}

The majority of waters and specimens within the national database originated from regional and local surveys and monitoring (Fig. 2). The strategy and coordination between national and local monitoring activities have, however, changed over time. The percentages of waters and number of specimens in nationally relative regionally coordinated monitoring activities between 1970 and 2000 were 1 and $12 \%$, respectively. A significant change in these proportions was seen after 2000 as the proportions of waters and number of specimens in national and regional monitoring 


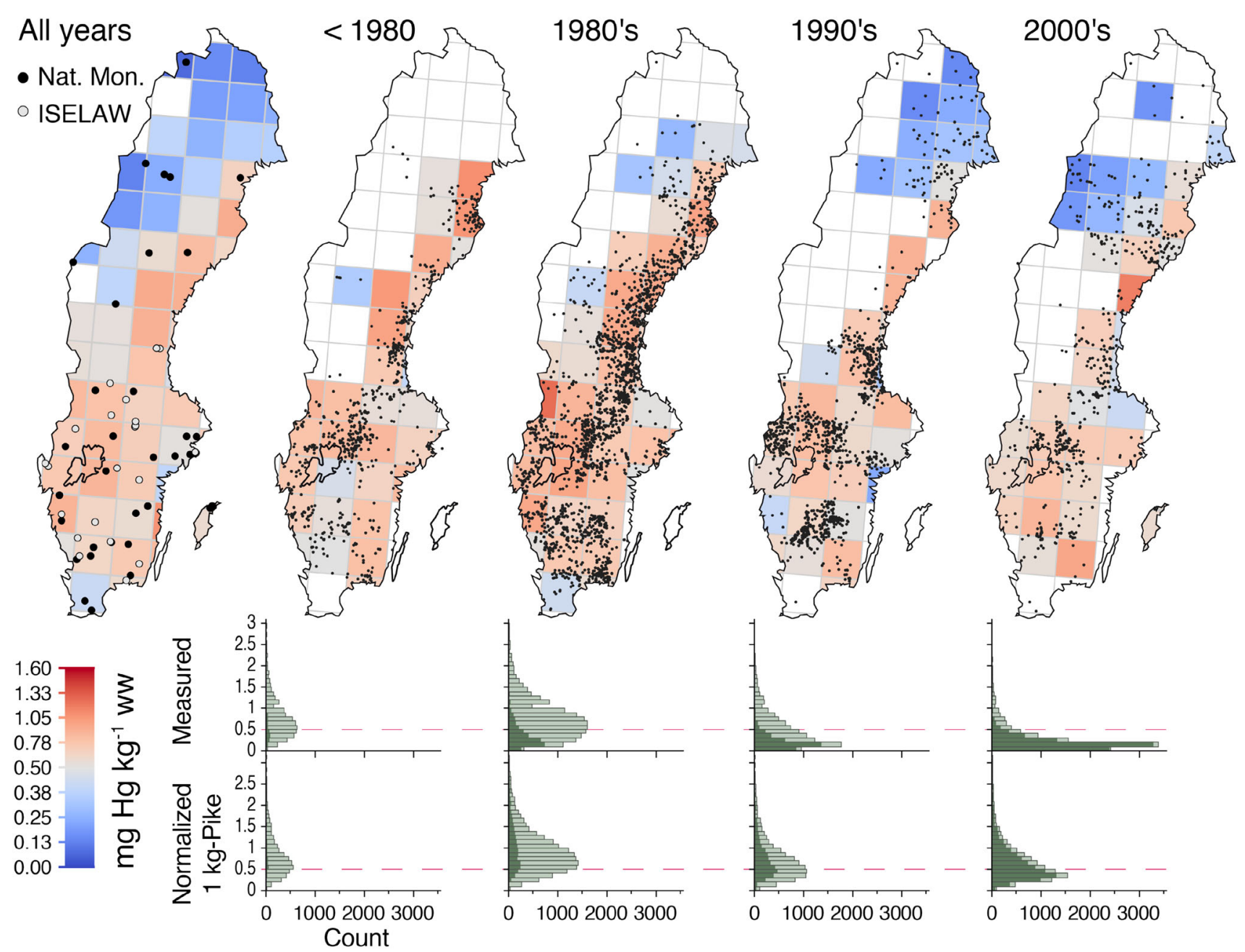

Fig. 1 Distribution of fish total ww $\mathrm{Hg}$ concentrations $\left(\mathrm{mg} \mathrm{Hg} \mathrm{kg}^{-1} \mathrm{ww}\right)$ in Swedish lakes over five decades. The map color represents the mean of lake means within a grid cell (European Environment Agency reference grid, $100 \mathrm{~km}$ ). Lake means were obtained after normalizing individual $\mathrm{Hg}$ concentrations in fish of all species and sizes to represent $\mathrm{Hg}$ in a typical 1-kg pike (see "Materials and methods" section). The leftmost map is based on all data from 1965 to 2012; 42000 individual fish from 2655 waters, including the lakes within the national monitoring and ISELAW programs (position shown in map). The four maps to the right illustrate the spatial distribution of sampling efforts (dots representing lakes sampled) and $\mathrm{Hg}$ concentrations during different time periods. Histograms show distributions of pike and perch $\mathrm{Hg}$ concentration before (upper row) and after normalization to 1-kg pike. The red reference lines denote the EU and FAO/WHO health advisory guideline for $\mathrm{Hg}$ in fish as food

increased to 11 and $68 \%$, respectively (Fig. 2). The longest nationally coordinated monitoring of $\mathrm{Hg}$ in freshwater fish has been conducted in lakes Bolmen and Storvindeln, from which dorsal muscle samples from northern pike have been collected since 1967 (SMNH 2011). Collection and analysis of $\mathrm{Hg}$ in perch from another 27 lakes have also been included between 1997 and 2007 in nationally coordinated programs. There has also been a shift in the target species used for monitoring of $\mathrm{Hg}$ in aquatic biota (Fig. 1). Northern pike was predominating between 1966 and 2000 $(89 \%)$, while perch was collected at higher abundances between 2000 and 2012 (69\%) (Fig. 1). The largest number of waters with fish $\mathrm{Hg}$ data in the database was reported between 1980 and $1989(n=2009)$ followed by a decrease in reported waters by almost $50 \%$, both between 1990 and $2000(n=1056)$ and from 2000 until $2012(n=573)$. Between 1965 and 1979, fish $\mathrm{Hg}$ data from 703 waters were reported to the database. Waters in northern Sweden have been reported more frequently since the 1980s.

\section{Swedish freshwater fish $\mathrm{Hg}$ concentrations compared to EQS}

The EQS for $\mathrm{Hg}$ in freshwater biota according to the WFD $\left(0.02 \mathrm{mg} \mathrm{kg}^{-1} \mathrm{ww}\right)$ was exceeded in all species and waters, except few individuals, within the database (Table 1; Fig. 1). In Arctic charr in Lake Abiskojaure, northernmost Sweden, the Hg concentrations exceeded the EQS manifold (1-35 times). Health advisory guidelines according to the FAO/WHO (0.5-1.0 mg MeHg kg ww) were also exceeded 
Table 2 The relative number of reported individual samples and lakes per $\mathrm{km}^{-2}$ land and water in reported fish $\mathrm{Hg}$ databases from Sweden (this study), Canada (Depew et al. 2013), USA (Chalmers et al. 2011), Ontario (Gandhi et al. 2014), and the Great Lakes region (Monson et al. 2011)

\begin{tabular}{lcclll}
\hline Country & $\begin{array}{l}\text { Total land } \\
\text { area }\left(\mathrm{km}^{2}\right)\end{array}$ & $\begin{array}{l}\text { Total water } \\
\text { area }\left(\mathrm{km}^{2}\right)^{\mathrm{a}}\end{array}$ & $\begin{array}{l}\text { Reported fish } \\
\text { individual } \\
\text { samples/lakes }\end{array}$ & $\begin{array}{l}\text { Relative number } \\
\text { of reported individual } \\
\text { samples per land } \\
\text { area/water area }\left(\mathrm{km}^{-2}\right)\end{array}$ & $\begin{array}{l}\text { Relative number } \\
\text { of reported lakes } \\
\text { per land area/water } \\
\text { area }\left(\mathrm{km}^{-2}\right)\end{array}$ \\
\hline Sweden & 407340 & 40080 & $44927 / 2881$ & $0.110 / 1.12$ & $0.0071 / 0.072$ \\
Canada & 9093507 & 891163 & $330000 / 5000$ & $0.036 / 0.37$ & $0.0005 / 0.006$ \\
USA & 9147593 & 377768 & $74867 / 7759$ & $0.008 / 0.20$ & $0.0008 / 0.021$ \\
Ontario, Canada & 917741 & 158654 & 97888 & $0.107 / 0.62$ & $0.003 / 0.18$ \\
Great Lakes & 2400000 & 350136 & 63872 & & \\
\hline
\end{tabular}

${ }^{a}$ Total land and water area for Sweden, Canada, and USA retrieved 8 July, 2014 from http://www.scb.se/statistik/MI/MI0802/2012A01/ MI0802_2012A01_SM_MI65SM1201.pdf, http://www.statcan.gc.ca/tables-tableaux/sum-som/101/cst01/phys01-eng.htm and http://www.census. gov/geo/reference/state-area.html, respectively

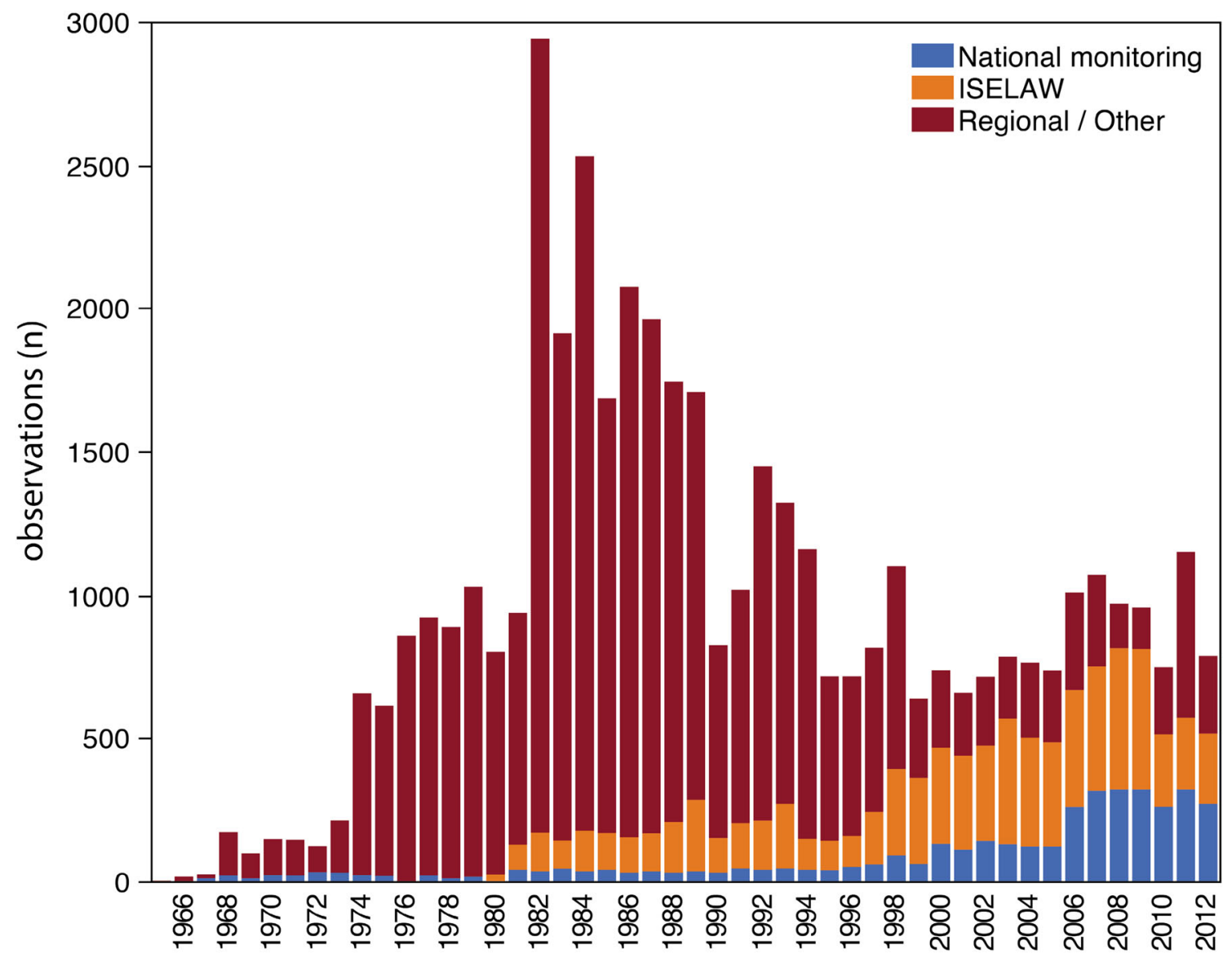

Fig. 2 Reported observations from national monitoring, ISELAW, and regional monitoring/survey or other studies

in more than half $(52.5 \%)$ of the waters in the database after 2000 (Fig. 1). The potential risk was not evenly distributed among Swedish lake ecosystems and it depended on, besides fish species, lake and catchment characteristics with high fish $\mathrm{Hg}$ concentrations in low productive humic lakes within forested catchments (Lindqvist et al. 1991; Sonesten 2003b). The main feature of the geographical pattern for $\mathrm{Hg}$ in fish was decreasing levels from south to north with the highest concentrations found in central Sweden and along the Swedish coast of the Gulf of Bothnia (Fig. 1). The elevated fish $\mathrm{Hg}$ concentrations in these areas may be influenced by historical emissions of $\mathrm{Hg}$ to both water and air as suggested by Lindqvist et al. (1991). However, ecosystem-specific characteristics also contributed to the variability in fish $\mathrm{Hg}$ concentrations between regions. This was also true for the southernmost part of 

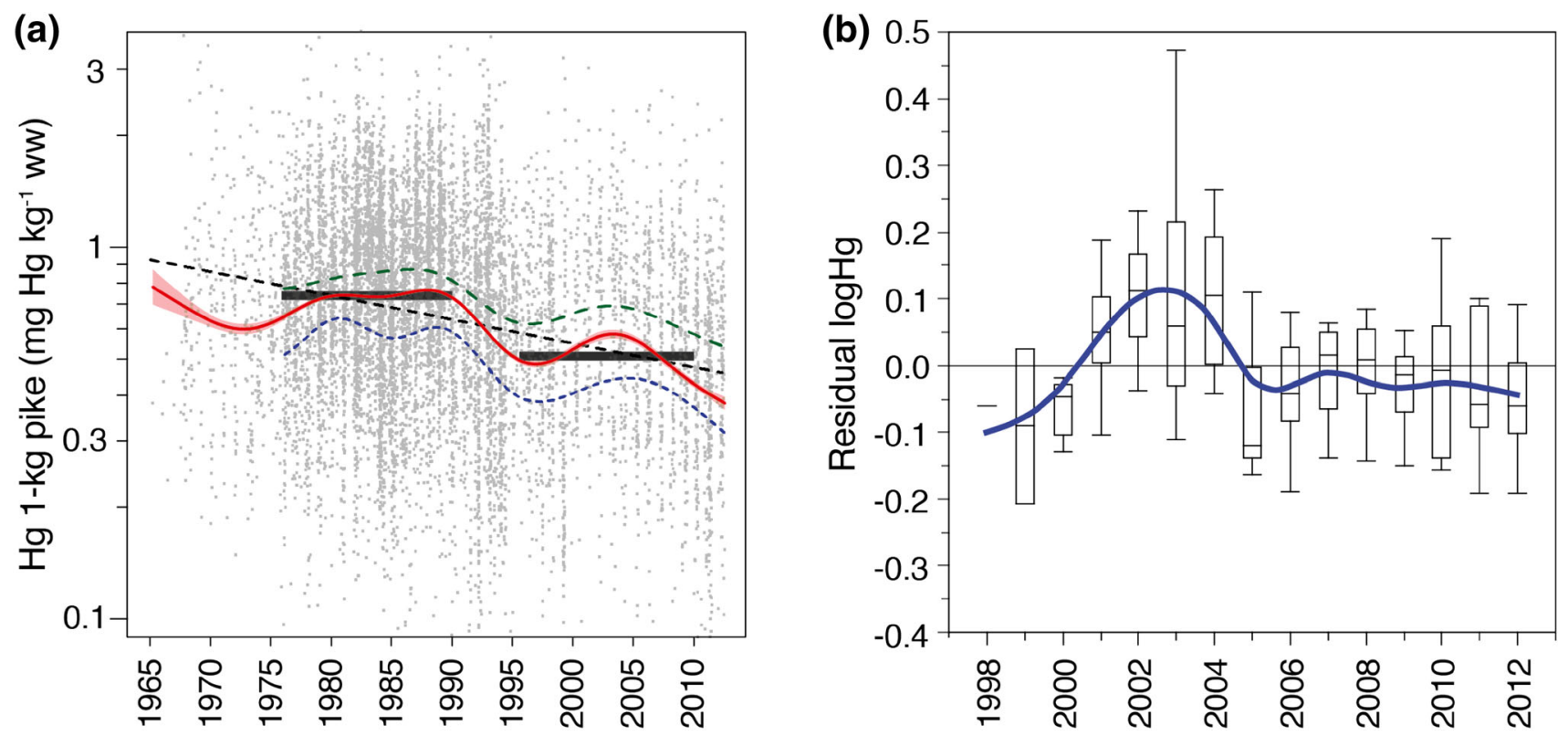

Fig. 3 Total Hg concentrations in Swedish fish 1965-2012. a Normalized (1-kg pike) Hg concentrations of 10176 catches; each point represents the mean from a single date and site. A linear regression model (black dashed line) and a GAM (red line \pm SE) were applied to all data to visualize temporal patterns. The parallel dashed lines are separate GAMs fitted either to limed lakes (upper green dashed line) or to never-limed lakes (lower blue dashed line). The black step lines indicate the geometric mean $\mathrm{Hg}$ concentrations between $1976-1990\left(0.74 \mathrm{mg} \mathrm{kg}{ }^{-1} \mathrm{ww}\right)$ and 1996-2010 (0.52 mg kg ${ }^{-1}$ ww). b Temporal pattern of untransformed $\mathrm{Hg}$ concentrations in medium-sized perch (total length 140-220 mm) from 11 national monitoring lakes during 1998-2012 (years 1998 and 1999 only represented by one and two lakes, respectively). Box-plots depict median, 25/75 and 2.5/97.5 percentiles, based on the distribution of residual $\mathrm{Hg}$ concentrations, i.e., deviation of annual log $\mathrm{Hg}$ from the withinlake mean for the period

Sweden, where low $\mathrm{Hg}$ concentrations were found despite a large burden from atmospheric deposition. These areas are mainly agricultural and the freshwater bodies mainly eutrophic, which may decrease $\mathrm{Hg}$ concentrations at higher trophic levels due to less $\mathrm{Hg}$ in diet (bio-dilution; Pickhardt et al. 2002) and higher growth rates (growth dilution; Verta 1990; Karimi et al. 2007).

The response of $\mathrm{Hg}$ concentrations in freshwater fish to changes in anthropogenic $\mathrm{Hg}$ emissions depends on factors affecting $\mathrm{Hg}$ cycling and bioaccumulation (e.g., catchment characteristics, water quality, trophic structure, and climate) (Munthe et al. 2007). The sensitivity of individual waters of transferring atmospheric $\mathrm{Hg}$ deposition to fish thus varies considerably (Harris et al. 2007; Orihel et al. 2007; Corbitt et al. 2011). The efforts to decrease $\mathrm{Hg}$ emissions by international agreements should assist freshwater ecosystems to recover from past $\mathrm{Hg}$ contamination but will also depend on other factors apart from a decrease in $\mathrm{Hg}$ emissions.

\section{Spatial and temporal changes}

\section{Large-scale changes}

Visualization of all the available data in maps and diagrams indicated that large-scale changes in fish $\mathrm{Hg}$ concentrations have occured over the last 50 years (Fig. 1). However, changes in intensity (Figs. 1, 2), geographical distribution (Fig. 1), and general objectives of the data collecting efforts require caution when delineating temporal trends. Linear regression based on the normalized concentrations of all fish suggested that $\mathrm{Hg}$ concentrations have decreased approximately $1 \%$ per year since 1970 $\left(R^{2}=0.051, p<0.001\right)$, corresponding to a decrease of about $30 \%$ during 40 years (Fig. 3a). A GAM fitted to the same data also indicated a long-term decrease, but following a more complex pattern (deviance explained = $8.3 \%, p<0.001$ ). According to the GAM, average $\mathrm{Hg}$ concentrations in 1-kg pike equivalents increased during the 1970s and peaked at the end of the 1980s before decreasing sharply between 1990 and 1996. During the late 1990s, Hg levels increased again and, after peaking by 2003, they appeared to have decreased up to present. The pattern of a reversed trend in the late 1990s also appeared for non-transformed $\mathrm{Hg}$ concentrations in perch from 11 annually sampled lakes (Fig. 3b). The two 15-year periods 1976-1990 and 1996-2010 appeared to represent two separate states with geometrical means of 0.74 and $0.52 \mathrm{mg}$ $\mathrm{Hg} \mathrm{kg}^{-1} \mathrm{ww}$, respectively. Thus, most of the observed $30 \%$ decline appeared to have occurred during the relatively short period between 1990 and 1996, while levels 
remained relatively constant 15 years before and after this transition period (Fig. 3a). Some of the sampled waters before the 1990s may not be representative because of a possible focus on lakes suspected or known to have a comparatively high $\mathrm{Hg}$ levels, e.g., locally polluted by point sources (Lindqvist et al. 1991).

Both the long-term decrease and rapid shift in $\mathrm{Hg}$ levels between 1976-1990 and 1996-2010 suggested by the GAM may, however, have been influenced by changes in monitoring strategies; for example, a shift from an earlier focus on acidified and lime-treated waters to the present focus on more pristine waters. Liming has been applied to surface waters to restore aquatic ecosystems from effects from acidification. In lakes with effective liming a 10 $20 \%$ decline in pike $\mathrm{Hg}$ concentrations have been observed (Meili 1995). Lakes in the limed group had on average considerably higher Hg concentration than lakes that were never subject to liming; possibly reflecting that many of these lakes were acidic or acidified. Here, the long-term temporal pattern was, however, quite similar in limed and non-limed waters as suggested by GAMs fitted to each subset of the data (Fig. 3a). Apparently, the shift in strategy from an earlier focus on acidified and lime-treated lakes to a relatively larger focus on pristine waters did not confound the long-term pattern in a major way. The observation here that changes in Hg levels roughly follow the same pattern,

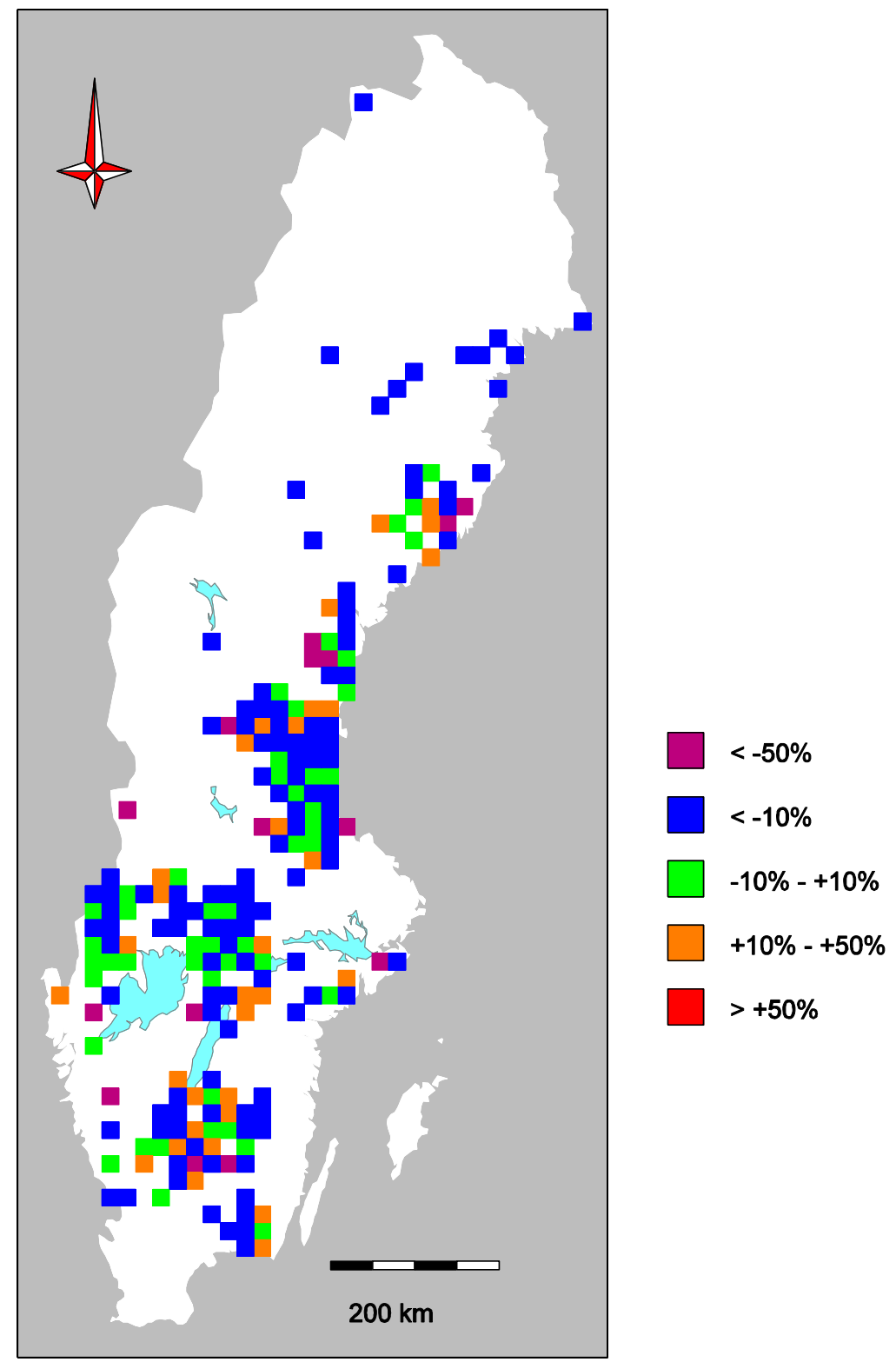

Fig. 4 Change in normalized (1-kg pike) total ww Hg concentrations based on 514 resampled lakes visited both 1965-1990 and 1991-2012. Colors show the mean change within $20 \times 20 \mathrm{~km}$ areas containing at least one resampled site. The average change was $-20 \%$ 


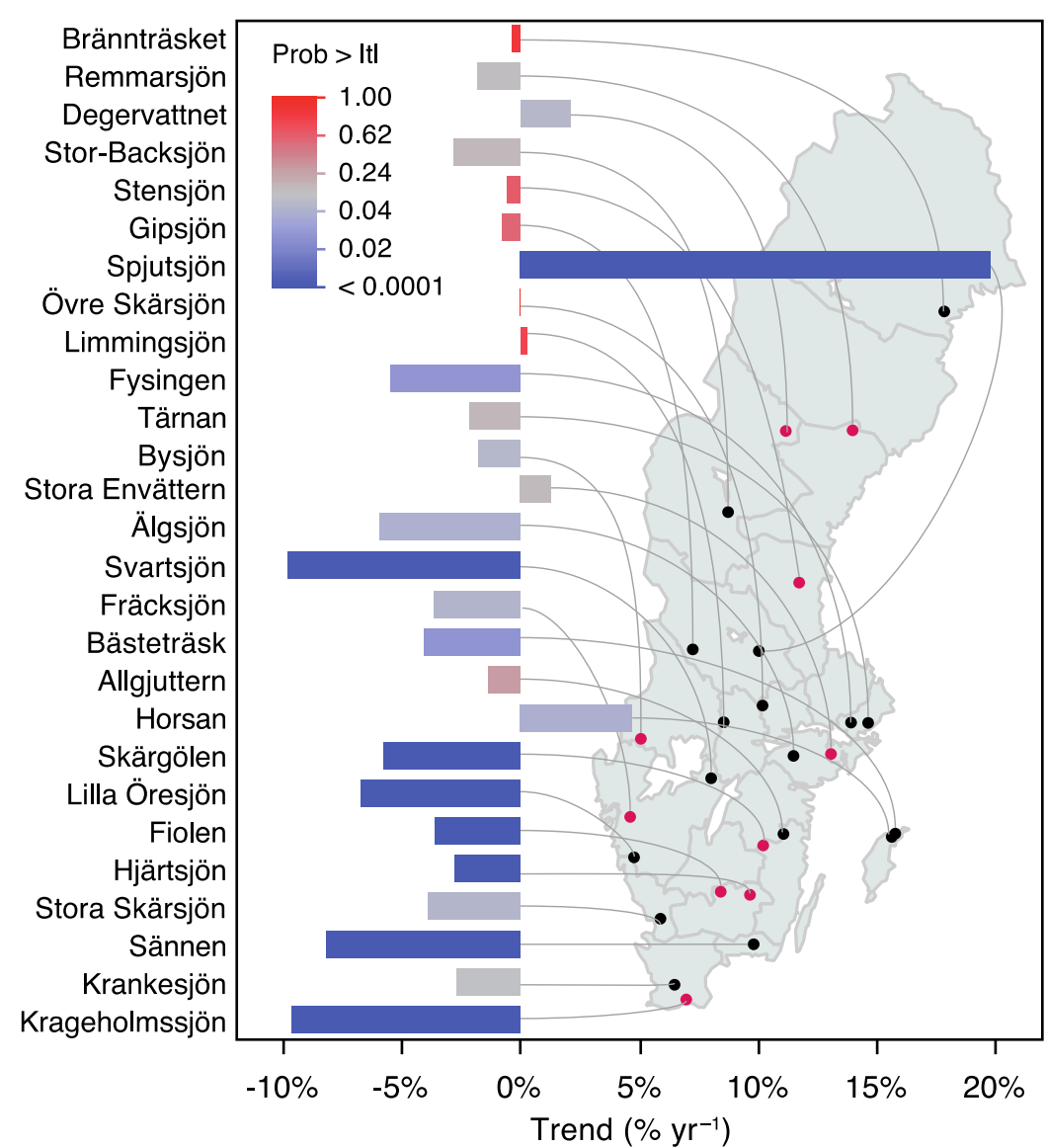

Fig. 5 Recent trends of total ww Hg concentrations in medium-sized perch (total length 140-220 mm) from 27 national monitoring lakes during the period 2003 (red dots, cf. Fig. 3b) or 2005/2006/2007 (black dots) to 2012. The lakes are ordered by latitude. Trends were estimated by linear regression on log-transformed $\mathrm{Hg}$ concentration normalized site specifically for fish age and body length. The bar color represents the probability of individual trends being equal to zero ( $t$ test). Blue bars highly significant, red bars not significant. Note the variable timing with respect to overall fluctuations such as the peak preceding 2005 (Fig. 3b)

irrespective of being based on subsets of normalized but heterogeneous data (Fig. 3a) or national monitoring time series (Fig. 3b), suggests that a common set of large-scale external forcing factors may exist.

To improve comparability over time, we divided the data into two time periods and restricted the data to only include waters that were sampled in both periods. For the periods 1965-1990 and 1991-2012, 514 resampled waters were identified. A comparison between the two periods shows a significant decrease in $\mathrm{Hg}$ concentrations (paired $t$ test: $p<0.001$, two-sided, $n=514)$. On average the decrease was $20 \%$, which was less than, but still comparable to, the $30 \%$ long-term decline found by linear regression and GAM on the extensive but much more heterogeneous dataset (Fig. 3a). A previous study compared $\mathrm{Hg}$ concentrations in perch (size adjusted to $200 \mathrm{~g} /$ $25 \mathrm{~cm}$ ) between 1974-1995 and 1996-2005 in Sweden that also showed a significant decrease of $21 \%$, while an increase of about $10 \%$ was found in Finland (Miller et al. 2013). An increase was also found in perch and brown trout collected from southeastern Norway between 1991 and 2008 (Fjeld and Rognerud 2009).

Regional differences in temporal trends were not evident from the data dominated by our normalized (1-kg pike) $\mathrm{Hg}$ concentrations (Fig. 4). Using the 514 resampled waters for spatiotemporal analysis, the current study showed that the change in fish $\mathrm{Hg}$ concentration was not evenly distributed. In some regions, we saw increasing $\mathrm{Hg}$ concentrations, but it was not possible to show a systematic geographical pattern in time trends using spatial analysis (Fig. 4). In several large areas of Sweden, it was not possible to find waters where $\mathrm{Hg}$ analysis were carried out in both periods (cf. Fig. 1).

In previous studies, shorter temporal (decadal) trend analysis of $\mathrm{Hg}$ concentration in freshwater fish has identified periods with increasing $\mathrm{Hg}$ concentrations as well as decreases in northern pike that fit well with the pattern observed herein. From the beginning of the 1970s until 2010, reported time trends in fish $\mathrm{Hg}$ concentration can roughly be divided into three phases. Fish $\mathrm{Hg}$ concentrations increased significantly during the 1970 s until 1980 s, followed by a 
decrease from the end of the 1980s until the 1990s (Håkanson et al. 1988; Johansson et al. 2001). The third phase has been estimated to last from the end of the 1990s and a decade forth, with pike $\mathrm{Hg}$ concentrations tending to increase in Swedish lakes (Åkerblom et al. 2012).

\section{Recent trends}

After a period of declining Hg levels (Johansson et al. 2001), recent reports about trends from Sweden (Åkerblom et al. 2012), Norway (Rognerud et al. 2009), and North America (French et al. 2006; Monson 2009; Gandhi et al. 2014) of increasing $\mathrm{Hg}$ concentrations in fish from the mid 1990s to about 2005 were discouraging. Now, with access to both longer time series and larger numbers of lakes in the national monitoring program, it is possible to further investigate whether the increasing trend persists or if it is a part of a more long-term, multiannual variation as suggested by Fig. 3a, b. The current national monitoring program includes 27 lakes where intermediately sized perch (total length 140-220 mm) are collected annually of which 10 similarly sized individuals are analyzed for $\mathrm{Hg}$, among other contaminants. A few of these lakes have been monitored for decades: about 10 lakes since 1998-2000 with the remainder added in 2005-2007 following the latest major revision of the national monitoring program (SMNH 2011). Individual fish length, weight, and age are routinely determined, which together with the abundance of data allows for a site-specific approach to account for individual and inter-annual variation.

The majority of the linear trend estimates were negative during the period of 2003 (or later for some lakes) to 2012, especially in waters in the southwestern part of Sweden where $\mathrm{Hg}$ concentrations decreased with up to $10 \%$ per year (Fig. 5). In the northern part, the trends were weaker and mostly not significant. In one lake, however, concentrations increased steeply with about $20 \%$ per year, which may indicate local anthropogenic sources of $\mathrm{Hg}$ (Fig. 5). Although this short-term trend analysis using 6-10 years of high-quality and consistent data suggests that $\mathrm{Hg}$ in fish is decreasing (again), it is not possible to conclude that this situation will persist, given the complex long-term dynamics discussed above.

\section{CONCLUSIONS}

Efforts to collect fishes, analyze samples, and report and collect fish $\mathrm{Hg}$ data over nearly 50 years enabled derivation of spatial and temporal patterns of Hg levels in Swedish freshwater fish. Fish $\mathrm{Hg}$ concentrations in Swedish waters are decreasing by approximately $1 \%$ per year between since 1970. The long-term temporal trends did not show any systematic geographical pattern, despite heterogeneity in controlling processes, such as historically changing atmospheric inputs of $\mathrm{Hg}$ (larger decrease in $\mathrm{Hg}$ loads in the south compared to the north of Sweden), catchment characteristics, and land use between regions. Despite decreasing trends, fish $\mathrm{Hg}$ concentrations are still high $(>0.5 \mathrm{mg} \mathrm{kg} \mathrm{ww})$ in several regions and health advisory guidelines for human consumption of freshwater fish are still relevant.

The coupling between aquatic species $\mathrm{Hg}$ concentrations and potential negative effects on ecosystem functioning depends on relevant biological indicators that can assist in the formulation of EQS for aquatic ecosystems. Variation in target species and size for bird and mammal as well as human consumption habits emphasizes the need for various target species in environmental monitoring strategies to protect ecological and human health according to criteria set by the WFD and WHO/FAO. The violation of the WFD EQS $\left(0.02 \mathrm{mg} \mathrm{kg}^{-1} \mathrm{ww}\right)$, even in remote and pristine waters, requires efforts to introduce measures from society to counteract possible negative effects on ecosystem health.

The observations made here, that inter-annual changes appear to happen synchronously to some extent (cf. Fig. 3b), are useful for future efforts in evaluation of the efforts to decrease emissions and use of $\mathrm{Hg}$ in products, which is the goal for the Minamata treaty (AMAP/UNEP 2013). The evaluation of source-receptor relationship between $\mathrm{Hg}$ emissions and $\mathrm{Hg}$ levels in freshwater ecosystems (cf. Meili et al. 2003) requires interdisciplinary research to determine the efficiency of international agreements (i.e., the Minamata treaty). Observations of direct and indirect consequences from reductions in $\mathrm{Hg}$ emissions in relation to $\mathrm{Hg}$ accumulation in freshwater ecosystems depend on continued monitoring of $\mathrm{Hg}$ levels in freshwater ecosystems within Sweden but also across nations and continents.

Acknowledgments The Swedish Environmental Protection Agency funded the national monitoring of $\mathrm{Hg}$ in Swedish freshwaters as well as a majority of the regional surveys. Analysis of $\mathrm{Hg}$ in fish specimen from the national monitoring were done by the Department of Applied Environmental Science (Stockholm University) and the Department of Aquatic Sciences and Assessment (SLU). We would like to express a special thanks to all people that assisted in the collection of fish that have been analyzed for $\mathrm{Hg}$ over the years.

Open Access This article is distributed under the terms of the Creative Commons Attribution License which permits any use, distribution, and reproduction in any medium, provided the original author(s) and the source are credited.

\section{REFERENCES}

Ackefors, H. 1971. Mercury pollution in Sweden with special reference to conditions in the water habitat. Proceedings of the Royal Society of London Series B-Biological Sciences 177: 365-387. 
Åkerblom, S., M.B. Nilsson, J. Yu, B. Ranneby, and K. Johansson. 2012. Temporal change estimation of mercury concentrations in northern pike (Esox lucius L.) in Swedish lakes. Chemosphere 86: 439-445.

AMAP/UNEP. 2013. Technical Background Report for the Global Mercury Assessment 2013. Arctic Monitoring and Assessment Programme, Oslo, Norway, vi +263 pp. Geneva: UNEP Chemicals Branch. Retrieved 7 July, 2014, from http://www. amap.no/documents/doc/technical-background-report-for-theglobal-mercury-assessment-2013/848.

Basu, N., A. Scheuhammer, N. Grochowina, K. Klenavic, D. Evans, M. O'Brien, and Chan, HM. 2005. Effects of mercury on neurochemical receptors in wild river otters (Lontra canadensis). Environmental Science and Technology 39: 3585-3591.

Björklund, I., H. Borg, and K. Johansson. 1984. Mercury in Swedish lakes: Its regional distribution and causes. AMBIO 13: 118-121.

Borg, K. 1959. Inverkan av betat utsäde på viltfaunan. VIIIth Nordic Veterinary Congress: Proceedings, pp. 394-400. Helsinki, Vammala (in Swedish).

Borg, K., H. Wanntorp, K. Erne, and E. Hanko. 1965. Mercury poisoning in wild animals and game and other birds in Sweden. In Kvicksilverförgiftningar bland vilt $i$ Sverige, 50 pp. Stockholm, Sweden: Statens Veterinärmedicinska Anstalt (SVA).

CA. 1995. Codex general standard for contaminants and toxins in food and feed. Codex Alimentarius. Codex Standard 1993-1995. Geneva: Food Agricultural Organisation of the United Nations, World Health Organisation (FAO/WHO )Joint Publications. Retrieved June 29, 2014, from http://www.codexalimentarius. org/download/standards/17/CXS_193e.pdf.

Castello, L., A.V. Zhulidov, T.Y. Gurtovaya, R.D. Robarts, R.M. Holmes, D.A. Zhulidov, V.S. Lysenko, and R.G.M. Spencer. 2014. Low and declining mercury in Arctic Russian Rivers. Environmental Science and Technology 48: 747-752.

Chalmers, A.T., D.M. Argue, D.A. Gay, M.E. Brigham, C.J. Schmitt, and D.L. Lorenz. 2011. Mercury trends in fish from rivers and lakes in the United States, 1969-2005. Environmental Monitoring and Assessment 175: 175-191.

Chan, H.M., A.M. Scheuhammer, A. Ferran, C. Loupelle, J. Holloway, and S. Weech. 2003. Impacts of mercury on freshwater fish-eating wildlife and humans. Human and Ecological Risk Assessment 9: 867-883.

CLRTAP. 2003. Convention on long-range transboundary air pollution on heavy metals-The 1998 Aarhus protocol on heavy metals. Geneva: United Nations-Economic Commission for Europe (UNECE). Retrieved June 26, 2014, from http://www. unece.org/env/lrtap/hm_h1.html.

Corbitt, E.S., D.J. Jacob, C.D. Holmes, D.G. Streets, and E.M. Sunderland. 2011. Global source-receptor relationships for mercury deposition under present-day and 2050 emissions scenarios. Environmental Science and Technology 45: 10477-10484.

Depew, D.C., N. Basu, N.M. Burgess, L.M. Campbell, E.W. Devlin, P.E. Drevnick, C.R. Hammerschmidt, C.A. Murphy, et al. 2012. Toxicity of dietary methylmercury to fish: Derivation of ecologically meaningful threshold concentrations. Environmental Toxicology and Chemistry 31: 1536-1547.

Depew, D.C., N.M. Burgess, M.R. Anderson, R. Baker, S.P. Bhavsar, R.A. Bodaly, C.S. Eckley, M.S. Evans, et al. 2013. An overview of mercury concentrations in freshwater fish species: A national fish mercury dataset for Canada. Canadian Journal of Fisheries and Aquatic Sciences 70: 436-451.

Eagles-Smith, C.A., and J.T. Ackerman. 2009. Rapid changes in small fish mercury concentrations in estuarine wetlands: Implications for wildlife risk and monitoring programs. Environmental Science and Technology 43: 8658-8664.

EC. 2006. Commission Regulation (EC) No 1881/2006. Setting maximum levels for certain contaminants in foodstuffs.
Commission Regulation (EC) No 1881/2006. Bruxelles: European Commission (EC).

EC. 2011. Common implementation strategy for the Water Framework Directive (2000/60/EC). Guidance document No. 27. Technical guidance for deriving environmental quality standards. European Commission, Technical Report-2011-2055. Bruxelles: European Commission (EC).

EP. 2000. Directive of the European parliament and of the council 2000/60/EC establishing a framework for community action in the field of water policy. Official Journal L 327, 22/12/2000. Strasbourg: European Parliament (EP).

EP. 2008. Directive 2008/105/EC of the European Parliament and of the Council on environmental quality standards in the field of water policy, amending and subsequently repealing Council Directives 82/176/EEC, 83/513/EEC, 84/156/EEC, 84/491/EEC, 86/280/EEC and amending Directive 2000/60/EC of the European Parliament and of the Council. Official Journal L 348/84, 24/12/2008. Strasbourg: European Parliament (EP).

Evers, D.C., L.J. Savoy, C.R. DeSorbo, D.E. Yates, W. Hanson, K.M. Taylor, L.S. Siegel, J.H. Cooley Jr, et al. 2008. Adverse effects from environmental mercury loads on breeding common loons. Ecotoxicology 17: 69-81.

Fjeld, E., and S. Rognerud. 2009. Miljøgifter i ferskvannsfisk, 2008. Kvikksфlv i abbor og organiske miljøgifter i фrret. Miljødirektoratet. TA-2544. Norsk institutt for vannforskning, Oslo, Norway (in Norwegian).

French, T.D., L.M. Campbell, D.A. Jackson, J.M. Casselman, W.A. Scheider, and A. Hayton. 2006. Long-term changes in legacy trace organic contaminants and mercury in Lake Ontario salmon in relation to source controls, trophodynamics, and climatic variability. Limnology and Oceanography 51: 2794-2807.

Gandhi, N., R.W.K. Tang, S.P. Bhavsar, and G.B. Arhonditsis. 2014. Fish mercury levels appear to be increasing lately: A report from 40 Years of monitoring in the Province of Ontario, Canada. Environmental Science and Technology 48: 5404-5414.

Håkanson, L., Å. Nilsson, and T. Andersson. 1988. Mercury in fish in Swedish lakes. Environmental Pollution 49: 145-162.

Harris, R.C., J.W.M. Rudd, M. Amyot, C.L. Babiarz, K.G. Beaty, P.J. Blanchfield, R.A. Bodaly, B.A. Branfireun, et al. 2007. Wholeecosystem study shows rapid fish-mercury response to changes in mercury deposition. Proceedings of the National Academy of Sciences of the United States of America 104: 16586-16591.

Johansson, K., B. Bergbäck, and G. Tyler. 2001. Impact of atmospheric long-range transport of lead, mercury and cadmium on the Swedish forest environment. Water, Air, \& Soil Pollution: Focus 1: 279-297.

Johnsson, C., G. Sällsten, A. Schütz, A. Sjörs, and L. Barregård. 2004. Hair mercury levels versus freshwater fish consumption in household members of Swedish angling societies. Environmental Research 96: 257-263.

Johnels, A.G., T. Westermark, W. Berg, P.I. Persson, and B. Sjöstrand. 1967. Pike (Esox lucius L.) and some other aquatic organisms in Sweden as indicators of mercury contamination in the environment. Oikos 18: 323-333.

Karimi, R., C.Y. Chen, P.C. Pickhardt, N.S. Fisher, and C.L. Folt. 2007. Stoichiometric controls of mercury dilution by growth. Proceedings of the National Academy of Sciences of the United States of America 104: 7477-7482.

Lavoie, R.A., T.D. Jardine, M.M. Chumchal, K.A. Kidd, and L.M. Campbell. 2013. Biomagnification of mercury in aquatic food webs: A worldwide meta-analysis. Environmental Science and Technology 47: 13385-13394.

Lindqvist, O., K. Johansson, M. Aastrup, A. Andersson, L. Bringmark, G. Hovsenius, L. Håkanson, A. Iverfeldt, et al. 1991. Mercury in the Swedish environment - Recent research on causes, consequences and corrective methods. Water, Air, and Soil pollution 55: 1-261. 
Meili, M. 1991. Mercury in fish - geographical and temporal perspectives. In Water, Air and Soil Pollution: Mercury in the Swedish environment-Recent research on causes, consequences and corrective methods, vol. ed. O. Lindqvist, 131157. Dordrecht: Kluwer.

Meili, M. 1995. Liming effects on mercury concentrations in fish. In Liming of Acidified Surface Waters-a Swedish Synthesis, ed. L. Henrikson and Y.W. Brodin, 383-398. Berlin: Springer. doi:10. 1007/978-3-642-79309-7_16.

Meili, M., K. Bishop, L. Bringmark, K. Johansson, J. Munthe, H. Sverdrup, and W. De Vries. 2003. Critical levels of atmospheric pollution: Criteria and concepts for operational modelling of mercury in forest and lake ecosystems. Science of the Total Environment 304: 83-106.

Meili, M., Kärrhage, P., and Borg, H. 2004a. Kvicksilver i fisk och födodjur i 10 skånska sjöar 2002. [Mercury in lacustrine fish and invertebrates from 10 lakes in Scania county, Sweden, in 2002]. Länsstyrelsen i Skåne län, Rapport Skåne i utveckling 2004:19, 26 pp. (ISSN 1402-3393) (in Swedish).

Meili, M., et al. 2004b. Modelling critical loads of metals for aquatic ecosystems: Critical levels of mercury in precipitation. In Manual on methodologies and criteria for modelling and mapping of critical loads \& levels and air pollution effects, risks and trends, chap. 5.5.3.2, pp. V.60-63. United Nations Convention on Long-Range Transboundary Air Pollution (UN/ ECE-CLRTAP-WGE-ICPMM). Retrieved July 7, 2014, from http://www.icpmapping.org/Mapping_Manual.

Mergler, D., H.A. Anderson, L.H.M. Chan, K.R. Mahaffey, M. Murray, M. Sakamoto, and A.H. Stern. 2007. Methylmercury exposure and health effects in humans: A worldwide concern. AMBIO 36: 3-11.

Miller, A., A. Bignert, P. Porvari, S. Danielsson, and M. Verta. 2013. Mercury in Perch (Perca fluviatilis) from Sweden and Finland. Water, Air, and Soil Pollution 224: 1472.

Monson, B.A. 2009. Trend reversal of mercury concentrations in piscivorous fish from Minnesota lakes: 1982-2006. Environmental Science and Technology 43: 1750-1755.

Monson, B.A., D.F. Staples, S.P. Bhavsar, T.M. Holsen, C.S. Schrank, S.K. Moses, D.J. McGoldrick, S.M. Backus, et al. 2011. Spatiotemporal trends of mercury in walleye and largemouth bass from the Laurentian Great Lakes Region. Ecotoxicology 20: 1555-1567.

Munthe, J., E. Fjeld, M. Meili, P. Porvari, S. Rognerud, and M. Verta. 2004. Mercury in Nordic freshwater fish: An assessment of spatial variability in relation to atmospheric deposition. In 7 th international conference on mercury as a global pollutant. RMZ Materials and Geoenvironment, vol. 51, 1239-1242. Ljubljana: ICMGP.

Munthe, J., R.A. Bodaly, B.A. Branfireun, C.T. Driscoll, C.C. Gilmour, R. Harris, M. Horvat, M. Lucotte, et al. 2007. Recovery of mercury-contaminated fisheries. AMBIO 36: 33-44.

NFA. 2012. Market Basket 2010—chemical analysis, exposure estimation and health related assessment of nutrients and toxic compounds in Swedish food baskets. Reports/risk AssessmentsRisk Benefits/Report No. 7-2012. Uppsala: National Food Agency (NFA).

Ohlin, B. 1982. Methylmercury content in fish and shellfish. Vår Föda 34: 103-105 (in Swedish).

Olsson, M. 1976. Mercury level as a function of size and age in northern pike 1 and 5 years after the mercury ban in Sweden. AMBIO 5: 73-76.

Orihel, D.M., M.J. Paterson, P.J. Blanchfield, R.A.D. Bodaly, and H. Hintelmann. 2007. Experimental evidence of a linear relationship between inorganic mercury loading and methylmercury accumulation by aquatic biota. Environmental Science and Technology 41: 4952-4958.
Petersson-Grawé, K., G. Concha, and E. Ankarberg. 2007. Riskvärdering av metylkvicksilver $i$ fisk. Rapport 10/2007. Uppsala: National Food Agency (in Swedish).

Pickhardt, P.C., C.L. Folt, C.Y. Chen, B. Klaue, and J.D. Blum. 2002. Algal blooms reduce the uptake of toxic methylmercury in freshwater food webs. Proceedings of the National Academy of Sciences of United States of America 99: 4419-4423.

Rognerud, S., I. Johansen, and E. Fjeld. 2009. Kvikksølv i ørret fra Sør-Norge, 2008. Report TA-2580. Oslo: Norwegian Environment Institute (NIVA) (in Norwegian).

Roos, A., E. Greyerz, M. Olsson, and F. Sandegren. 2001. The otter (Lutra lutra) in Sweden-population trends in relation to $\Sigma$ DDT and total PCB concentrations during 1968-99. Environmental Pollution 111: 457-469.

Scheuhammer, A.M., M.W. Meyer, M.B. Sandheinrich, and M.W. Murray. 2007. Effects of environmental methylmercury on the health of wild birds, mammals, and fish. AMBIO 36: 12-18.

SMNH. 2011. The national Swedish contaminant monitoring programme for freshwater biota, 2011. Report No. 14:2011. Stockholm: Department of Contaminant Research, Swedish Museum of Natural History (SMNH) (in Swedish).

Sonesten, L. 2003a. Fish mercury levels in lakes—adjusting for $\mathrm{Hg}$ and fish-size covariation. Environmental Pollution 125: 255-265.

Sonesten, L. 2003b. Catchment area composition and water chemistry heavily affects mercury levels in perch (Perca fluviatilis L.) in circumneutral lakes. Water, Air, and Soil pollution 144: 117139.

Sundbom, M. 2009. Kalkningseffekter på kvicksilver i fisk. In Utvärdering av IKEU 1990-2006, ed. J. Munthe and A. Jöborn, 202-213. Report 6302. Stockholm: Environmental Protection Agency (in Swedish).

UNEP. 2013. The Minamata convention on mercury. GE.13-01543. Retrieved July 8, 2014, from http://www.mercuryconvention. org/Convention/tabid/3426/Default.aspx. Geneva: United Nations (UN).

Verta, M. 1990. Changes in fish mercury concentrations in an intensively fished lake. Canadian Journal of Fisheries and Aquatic Sciences 47: 1888-1897.

Watras, C.J., and N.S. Bloom. 1992. Mercury and methylmercury in individual zooplankton: Implications for bioaccumulation. Limnology and Oceanography 37: 1313-1318.

Watras, C.J., R.C. Back, S. Halvorsen, R.J.M. Hudson, K.A. Morrison, and S.P. Wente. 1998. Bioaccumulation of mercury in pelagic freshwater food webs. The Science of the Total Environment 219: 183-208.

Wood, S.N. 2011. Fast stable restricted maximum likelihood and marginal likelihood estimation of semiparametric generalized linear models. Journal of the Royal Statistical Society (B) 73: 336.

\section{AUTHOR BIOGRAPHIES}

Staffan Åkerblom $(\bowtie)$ is a researcher at Swedish University of Agricultural Sciences. His research deals with aspects of $\mathrm{Hg}$ biogeochemistry, including processes affecting the turnover and exposure of heavy metals and mercury.

Address: Department of Aquatic Sciences and Assessment, SLU, P.O. Box 7050, 75007 Uppsala, Sweden.

e-mail: staffan.akerblom@slu.se

Anders Bignert is a Researcher and Professor in ecotoxicology at the Swedish Museum of Natural History. His research interest includes environmental monitoring, especially contaminants in biological matrices.

Address: Department of Environmental Research and Monitoring, 
Swedish Museum of Natural History, P.O. Box 50007, 10405 Stockholm, Sweden.

e-mail: anders.bignert@nrm.se

Markus Meili is an Associate Professor in Biogeochemistry at Stockholm University, after positioned in Limnology and Earth Sciences. His research interest is the coupled cycling of contaminants and nutrients in aquatic ecosystems and includes the tracing of biotic and biotic processes in food webs, sediments, and watersheds, often based on various isotopes.

Address: Department of Applied Environmental Science (ITM), Stockholm University, 10691 Stockholm, Sweden.

e-mail: Markus.Meili@itm.su.se

Lars Sonesten is a Researcher and Vice Head of the Department at the Swedish University of Aquatic Sciences and Assessment at SLU, Uppsala, Sweden. His research interests include evaluation of long- term trends in water chemistry and biological composition, risk assessment of heavy metals and organic pollutants in freshwater, biota, and sediments.

Address: Department of Aquatic Sciences and Assessment, SLU, P.O. Box 7050, 75007 Uppsala, Sweden.

e-mail: Lars.Sonesten@slu.se

Marcus Sundbom is a Research Assistant in Biogeochemistry and Head of Analytical Facilities at Stockholm University. He evaluates long-term monitoring data to address research topics such as the fate of contaminants in food webs and the effects acidification and liming on aquatic ecosystems.

Address: Department of Applied Environmental Science (ITM), Stockholm University, 10691 Stockholm, Sweden.

e-mail: Marcus.Sundbom@itm.su.se 